\author{
Anna Wojnarska \\ Katarzyna Korona \\ Instytut Pedagogiki Zakład Pedagogiki Resocjalizacyjnej, UMCS Lublin
}

\title{
Poczucie osamotnienia a nieprzystosowanie społeczne
}

Prezentowany artykuł dotyczy przeglądu powiązań między poczuciem osamotnienia i nieprzystosowaniem społecznym. Poczucie osamotnienia, w przeciwieństwie do samotności, ma zawsze konsekwencje negatywne zarówno w sferze psychicznej, jak i społecznej. Przyczynami jego nasilania się są zmiany społeczne i obyczajowe, niewydolność wychowawcza środowiska rodzinnego i szkolnego oraz zastępowanie bezpośrednich interakcji społecznych kontaktami pośrednimi poprzez media. Osobowościowymi korelatami poczucia osamotnienia są: neurotyczność, introwersja, poczucie bezradności, niskie poczucie własnej skuteczności i niska samoocena. Konsekwencje poczucia osamotnienia są obserwowalne w postaci nasilania się depresji, prób samobójczych, agresji, zachowań ryzykownych i wiktymizacji. Proponowane kierunki działań praktycznych w procesie profilaktyki i resocjalizacji koncentrują się głównie na stworzeniu okazji do kształtowania satysfakcjonujących wzorców relacji interpersonalnych.

Słowa kluczowe: poczucie osamotnienia, samotność, alienacja, wiktymizacja, uzależnienia, depresja

\section{The Sense of Loneliness and Social Maladjustment}

The paper concerns the sense of loneliness and social maldjustment. The sense of loneliness, contrary to loneliness itself, results in negative mental and social consequences. The reasons behind the increasing sense of loneliness are social and moral changes, educational helplessness of the family and school, as well as replacing face-to-face interaction with media supported contacts. Personality factors that correlate with the sense of loneliness are neurotism, introversion, helplesseness, lower self- efficacy and lower self-esteem. Increasing sense of loneliness generates depression, suicidal attempts, aggression, multiple risk behaviour, and victimization. Suggested directions for practical action in diagnosis and social theraphy concentrate mainly on creating opportunities for forming satisfactory models of interpersonal relationships.

Keywords: sense of loneliness, loneliness, alienation, victimization, addiction, depression 


\section{Samotność - poczucie osamotnienia - alienacja - rozważania definicyjne}

Samotność jest zjawiskiem wielowymiarowym towarzyszącym rozwojowi społecznemu człowieka. Warto zauważyć przenikanie się teorii filozoficznych, socjologicznych i psychologicznych analizujących zagadnienie samotności.

Egzystencjaliści twierdzą, że odczuwanie samotności jest immanentną cechą ludzkiego istnienia i rozwój człowieka polega na kreatywnym wykorzystaniu tego stanu przez konfrontację z samym sobą i zwróceniem się ku wartościom transcendentnym [Jaspers 1951; Marcel 1962, za: Dołęga 2003, s. 13]. Natomiast w ujęciu fenomenologicznym samotność jest formą złego przystosowania uwarunkowanego predyspozycjami osobistymi [Rembowski 1992].

Według socjologów samotność jest funkcją systemu opartego na zewnątrzsterowności i wynika z przyczyn obiektywnych, takich jak kryzysowe wydarzenia [Rembowski 1992]. W perspektywie antropologiczno-socjologicznej problem ten jest kojarzony z alienacją i anomią społeczną na poziomie makrospołecznym, a jednocześnie z odczuwaniem przez jednostkę zagubienia, odseparowania, braku lub utraty wartości, norm i zasad społecznych. W ten sposób niepowodzenia $\mathrm{w}$ relacjach interpersonalnych zostają przeniesione do sfery intrapsychicznej [Dołęga 2003]. Analizy socjologów akcentują zjawiska szczególnie niebezpieczne w czasach nadmiaru informacji, dóbr i kontaktów, które nasilają negatywne emocje człowieka i utrudniają mu zbudowanie satysfakcjonujących związków z innymi ludźmi.

Koncepcje psychologiczne zwracają uwagę na złożoność fenomenu samotności, który powinien być analizowany ze względu na następujące wymiary: podmiotowość (kto ma poczucie samotności), relacyjność (wobec kogo/czego czuje się samotny), temporalność (samotność chwilowa, chroniczna), sposób wartościowania (pozytywne, negatywne, ambiwalentne) oraz stopień podmiotowej kontroli (samotność przymusowa lub z wyboru). Koncepcje psychodynamiczne zwracają uwagę na znaczenie pierwszych więzi emocjonalno-społecznych dla modelowania relacji intymności. Neopsychoanalitycy podkreślali destruktywne i dezintegrujące znaczenie samotności prowadzącej do zaburzeń psychotycznych i tym tłumaczyli pojawianie się zachowań destruktywnych i autodestruktywnych. Podejście kognitywne akcentuje znaczenie subiektywnych interpretacji sytuacji przez człowieka, co zbliża to stanowisko do koncepcji interakcjonizmu symbolicznego H. Meada [Dołęga 2003; Rembowski 1992].

Jedną z najbardziej popularnych prób klasyfikacji samotności jest koncepcja interakcyjna R.Weissa [Oleś 2006], który dokonał rozróżnienia na samotność emo- 
cjonalną i społeczną. Zasadność podziału argumentuje faktem, że w przypadku adolescentów i dorosłych mają one różną genezę oraz różną podatność na niwelowanie, a także różne są ich konsekwencje psychopatologiczne [Dołęga 2003, s. 44-46].

Poczucie osamotnienia odzwierciedla rozbieżność pomiędzy oczekiwaniami dotyczącymi relacji społecznych a ich rzeczywistą realizacją [Asher i in. 1990, za: Heiman, Margalit 1998]. Jest to emocjonalna odpowiedź jednostki na rozbieżność pomiędzy pożądanym a osiągniętym poziomem kontaktów społecznych [Shaver, Brennan, 1991, za: Chodkiewicz, Świątkowska 2007]. Pomimo że w literaturze pojęcia samotności i osamotnienia są często stosowane zamiennie, to wielu badaczy dokonuje ich zróżnicowania (tab. 1).

Tabela 1. Porównanie pojęć samotność a osamotnienie

\begin{tabular}{|l|l|}
\hline \multicolumn{1}{|c|}{ Samotność } & \multicolumn{1}{c|}{ Osamotnienie } \\
\hline Wymiar obiektywny/ subiektywny & Wymiar subiektywny \\
\hline Może być chwilowa lub chroniczna & Zawsze jest chroniczna \\
\hline Stanowi wynik braku kontaktów z ludźmi & $\begin{array}{l}\text { Może towarzyszyć sytuacjom licznych, powierz- } \\
\text { chownych kontaktów }\end{array}$ \\
\hline Może być świadomym wyborem & Spostrzegana jako przymus \\
\hline Sprzyja rozwojowi osobowemu, kreatywności & Nasila poczucie bezradności \\
\hline Sprzyja dojrzałej osobowości & $\begin{array}{l}\text { Może prowadzić do dezintegracji osobowości, } \\
\text { depresji, samobójstw }\end{array}$ \\
\hline $\begin{array}{l}\text { Chwilowa jest korzystna dla zdrowia psycho- } \\
\text { fizycznego, chroniczna negatywna }\end{array}$ & $\begin{array}{l}\text { Niekorzystna dla zdrowia somatycznego } \\
\text { i psychicznego }\end{array}$ \\
\hline $\begin{array}{l}\text { Samotności z wyboru mogą towarzyszyć emocje } \\
\text { pozytywne, poczucie relaksu }\end{array}$ & $\begin{array}{l}\text { Poczuciu osamotnienia zawsze towarzyszą } \\
\text { emocje negatywne, lęk, stres }\end{array}$ \\
\hline
\end{tabular}

Źródło: Opracowanie własne na podstawie [Dołęga 2003; Kościelak 1996; Rembowski 1992; Sendyk 2011; Szczupał 2005].

Samotność egzystencjalną charakteryzuje stan braku identyfikacji z normami, celami życiowymi i rolami społecznymi, co powoduje dezintegrację osobowościową. Często ten stan jest określany jako alienacja lub samoalienacja i charakteryzuje się „wewnętrzną pustką, poczuciem nicości, utratą pewnych aspektów tożsamości, niezdolnością do rozumienia siebie i świata, braku poczucia sensu życia, poczuciu beznadziejności i utraty kontroli nad własnym życiem oraz przekonaniem o bezbronności jednostki wobec okoliczności życia" [Dołęga 2003, s. 25]. Takie przekonania decydują o ukształtowaniu się światopoglądu nacechowanego nihilizmem, cynizmem i pesymizmem. Poczucie alienacji/zakorzenienia odnosi 
się do poczucia jednostki bycia oderwanym od istotnych dla niej obszarów rzeczywistości społecznej oraz ważnych sfer osobistego funkcjonowania. Alienacja jest rozpatrywana, $\mathrm{z}$ jednej strony, $\mathrm{w}$ aspekcie socjologicznym $\mathrm{w}$ powiązaniu ze specyfiką warunków życia społecznego, a z drugiej - w aspekcie psychologicznych w kontekście oczekiwań i nastawień poznawczych [Czerwińska-Jakimiuk 2012]. Alienacja prowadzi do oderwania się jednostki od kontekstu kulturowego i społecznego, często przybierając formę buntu wobec systemu. Według M. Seemana [1995 za: Kmiecik-Baran 1995] alienacja może przybierać postać: poczucia bezradności (oczekiwanie braku wpływu na realizację dążeń), poczucia bezsensu (przekonanie o braku wartości podejmowanych działań połączone z trudnością przewidywania ich skutków), poczucia anomii (negowanie reguł systemu społecznego), poczucia izolacji społecznej - osamotnienia (przekonanie o braku możliwości „nawiązywania satysfakcjonujących związków z innymi ludźmi”), poczucie samowyobcowania (oderwanie postępowania jednostki od własnych zasad i przekonań). Poczucie wyalienowania jest przyczyną obniżenia poziomu osobistej skuteczności, nasilania wyuczonej bezradności, obniżenia poczucia jakości życia [Niewiadomska, Chwaszcz 2010], zachowań dewiacyjnych i agresywnych [Tomaszek, Tucholska 2012] wzmacniających proces marginalizacji społecznej. Termin „alienacja” należy uznać za najbardziej pojemny zawierający w sobie pojęcie samotności, jak i poczucie osamotnienia.

\section{Przyczyny poczucia samotności}

Przyczyny przeżywania poczucia samotności są natury społecznej i osobowościowej. Zmiany cywilizacyjne obserwowalne w ciągu ostatnich dekad powodują trudności w kształtowaniu satysfakcjonujących relacji interpersonalnych. Tempo życia związane z gospodarką rynkową decyduje o dehumanizacji życia i traktowaniu człowieka w sposób przedmiotowy w charakterze "towaru" [Perski 2002]. Skrajną postacią alienacji jest syndrom hikikomori manifestujący się $\mathrm{w}$ postaci całkowitej izolacji młodego człowieka, czasami połączonej z obsesyjnym korzystaniem z komputera i Internetu [Tomaszek, Tucholska 2012]. Rozwój mediów komunikacyjnych powoduje problemy w komunikacji bezpośredniej, czego egzemplifikacją jest „samotność w sieci”, czyli sytuacja, gdy użytkownik portali społecznościowych ma dużo znajomych, ale w życiu realnym nie ma żadnych przyjaciól. Zmiany społeczno-kulturowe są przyczyną pojawiania się takich niepokojących zjawisk, jak: zwiększanie się liczby zachorowań na depresję, nasilanie 
się prób samobójczych, coraz większa liczba rodzin niepełnych i osób żyjących samotnie ${ }^{1}$.

Mechanizmem chroniącym małe dziecko przed poczuciem osamotnienia jest kształtowanie się przywiązania do jednej ważnej osoby w okresie niemowlęcym i poniemowlęcym. Relacja z osobą znaczącą, powstała w okresie krytycznym, jest kluczowa dla dalszego rozwoju dziecka zarówno w sferze emocjonalno-społecznej, jak i intelektualnej [Vasta, Haith, Miller 1995]. Prototypowe wzorce relacji emocjonalno-społecznych determinują ukształtowanie się trzech zasadniczych modeli przywiązania: bezpiecznego, lękowo-ambiwalentnego i lękowo-unikającego, z czego tylko pierwszy jest czynnikiem zapobiegającym osamotnieniu. Pozostałe są czynnikami zwiększającymi m.in. ryzyko zaburzeń depresyjnych [Mushtaq i in. 2014].

Kryzys współczesnej rodziny wyrażający się osłabieniem więzi emocjonalnych z powodu powierzchowności kontaktów, braku czasu poświęcanego dziecku, zaabsorbowania rodziców karierą zawodową powoduje nasilanie się zjawiska samotności dziecka w pozornie prawidłowej rodzinie. Zwiększa się liczba tzw. eurosierot, które pozostają w faktycznej izolacji wobec rodziców i są wychowywane przez osoby nie zawsze do tego przygotowane i chętne. Dodatkowym czynnikiem nasilania się samotności dziecka w rodzinie są patologie, m.in.: przemoc, alkoholizm, przestępczość, które powodują odrzucenie dziecka. Rodziny te najczęściej prezentują system rodzin uwikłanych, chaotycznych lub rodzin władzy. Spośród trzech wymiarów chrakteryzujących systemy rodzinne okazuje się, że przede wszystkim spójność systemu decyduje o zdrowym rozwoju społecznym, natomiast jego adaptacyjność nie ma znaczenia. Dzieci z rodzin o wysokim wskaźniku spójności charakteryzują się niskim poziomem poczucia samotności, są silne psychiczne i manifestują pozytywne oczekiwania wobec przyszłości [Sharabi, Levi, Margalit 2012].

Badania wychowanków domu dziecka wykazały, że czynnikiem chroniącym przed odczuwaniem osamotnienia dzieci jest poczucie koherencji. Dzieci, które spostrzegały swoją sytuację jako tymczasową, łatwiej przezwyciężały poczucie braku bliskości z rodziną i były aktywniejsze, co znalazło swoje potwierdzenie $\mathrm{w}$ negatywnych umiarkowanych korelacjach pomiędzy miarami poczucia osamotnienia i koherencji [Tracz 2010].

$\mathrm{W}$ odniesieniu do młodzieży $\mathrm{w}$ wieku dorastania stwierdzono znaczący wpływ wsparcia społecznego ze strony osób znaczących, takich jak: rówieśnicy, rodzice, nauczyciele [Dołęga 2003]. Okres ten charakteryzuje się poszukiwaniem

1 Według szacunków socjologów już w ciągu najbliższych lat liczba "singli" może stanowić nawet $30 \%$ populacji [Tyszka 2003]. Z danych Eurostatu wynika, że odsetek gospodarstw jednoosobowych spadł z 54\% w roku 2005 do 45\% w roku 2015. Pod tym względem wynik wyższy niż Polska osiągnęły: Serbia, Bułgaria czy Węgry (z 23 porównywanych krajów Europy). 
własnej tożsamości przez krytyczny stosunek do prezentowanych przez dorosłych wartości i nowych autorytetów. Z tych powodów młodzież w okresie adolescencji poszukuje samotności, która pozwala przemyśleć wiele spraw i ustosunkować się do otaczającej rzeczywistości społecznej. Młodzież podkreśla pozytywne aspekty samotności akcentując jej kontemplacyjny charakter sprzyjający kształtowaniu się autonomii. Jednak pozytywne aspekty samotności wynikają z tego, że samotność ta jest dobrowolna i przejściowa [Dołęga 2003; Kleszcz, Łączyk 2012; Tomaszek, Tucholska 2012].

Kolejną przyczyną poczucia osamotnienia są deficyty poznawcze i emocjonalne, będące częstym powodem odrzucenia rówieśniczego i wiktymizacji, Warunkiem pojawienia się poczucia osamotnienia wśród dzieci z trudnościami w uczeniu się jest: świadomość deficytu, przejawy deficytu (reakcja na frustracje, brak zrozumienia sytuacji), lęk społeczny w zachowaniu (ambiwalencja w dążeniu do kontaktu) i trudności w komunikacji [Shaughnessy 2008]. Dzieci z trudnościami w komunikacji mają mniej wsparcia od rówieśników, nie potrafią się obronić ze względu na mniejsze zdolności ekspresji, mają trudności z wchodzeniem w interakcje, wyrażaniem potrzeb, zgłaszaniem ataków. E.A. Storch i in. [2003] na podstawie badania 205 dzieci w wieku 10-13 lat stwierdzili, że poczucie trudności $\mathrm{w}$ komunikacji koreluje z wiktymizacją otwartą i relacyjną ${ }^{2}$, z depresyjnością i poczuciem osamotnienia.

W przypadku osób niepełnosprawnych intelektualnie pojawiają się dodatkowe uwarunkowania nasilające odczucie izolacji społecznej. Dzieci te manifestują więcej zaburzeń w zachowaniu w postaci agresji, wycofania się i fobii, które wynikają z wysokiego poziomu lęku, impulsywności, niskiej samooceny i tolerancji na frustrację. Deficyty w sferze poznawczej, takie jak trudności w percepcji i interpretacji sygnałów społecznych, zaburzenia koncentracji uwagi, pamięci i opóźniony rozwój mowy, utrudniają nawiązywanie kontaktów społecznych [Papoutsaki, Gena, Kalya 2013].

\section{Osobowościowe korelaty poczucia samotności}

Można oczekiwać, że wysokie poczucie osamotnienia jest powiązane z wysokim poziomem neurotyczności. Osoby osamotnione charakteryzuje napięcie związane z przekonaniem o przyszłych trudnościach, poczucie braku perspektyw życiowych i niemożność realizacji planów oraz aspiracji powiązane z poczu-

2 Wiktymizacja otwarta polega na krzywdzeniu innych poprzez fizyczne ataki lub groźbę tych ataków, natomiast relacyjna dotyczy czynienia szkody poprzez manipulacje i destrukcje np. roz- powszechnianie plotek, odrzucenie [Storch i in. 2003, s. 1]. 
ciem poznawczego i emocjonalnego „oderwania od wartości (poczucie bezsensu) [Chodkiewicz, Świątkowska 2007; Czerwińska-Jakimiuk 2012]. Jednocześnie realna samotność powoduje koncentrowanie się na swoim wnętrzu i nasilanie dolegliwości towarzyszących neurotyzmowi - lęku, dolegliwości psychosomatycznych, pesymizmu.

Natomiast wbrew oczekiwaniom introwersja nie musi korelować z poczuciem osamotnienia, ponieważ osoby introwertywne preferują samotność, ale nie odczuwają związanego z nią dyskomfortu. W grupie tej duży procent stanowią także osoby ambiwertywne [Oleś 2006], choć wiele badań potwierdza istnienie zależności między introwersją a samotnością [Dołęga 2003]. Zauważono jednak, że umiejętność otwierania się na innych, odsłaniania swoich osobistych problemów i korzystania z pomocy innych ludzi, czyli umiejętność korzystania ze wsparcia i udzielania tego wsparcia koreluje negatywnie z poczuciem osamotnienia i pozytywnie z poziomem kompetencji społecznych [Argyle 1999].

Najczęściej badania nad osamotnieniem odwoływały się do dwóch głównych teorii: potrzeb społecznych i poznawczych. W zakresie poznawczych aspektów osobowości wysokie poczucie osamotnienia koreluje z takimi cechami jak niska samoocena, niskie poczucie własnej wartości, niskie poczucie własnej sprawczości, zewnętrzne poczucie kontroli [Czerwińska-Jakimiuk 2012; Tomaszek, Tucholska 2012; Oleś 2006]. Struktury poznawcze takich osób posiadają swoiste własności w postaci niestabilności, sztywności, nieelastyczności, nietrwałości reprezentacji poznawczej własnego „JA", świata zewnętrznego, relacji ",ja-inni”, uproszczenia i deformacje poznawcze [Jakubik, Kraszewska 2002]. Specyfika ta zbliża poczucie osamotnienia do triady depresyjnej w ujęciu A. Becka, która manifestuje się w postaci negatywnych myśli dotyczących siebie, świata i przyszłości.

Podsumowując rozważania dotyczące osobowościowych korelatów poczucia osamotnienia należy podkreślić, że pytanie o kierunek zależności między tymi zmiennymi nie jest nadal rozstrzygnięte. Wielkość współczynników korelacji pomiędzy analizowanymi zmiennymi osiąga poziom niski i umiarkowany. Rodzaj zależności między analizowanymi cechami osobowości a poczuciem osamotnienia prawdopodobnie nie ma charakteru liniowego, o czym mogą świadczyć próby włączenia tej zmiennej do modeli regresyjnych i analizy skupień. Ponadto wydaje się, że z punktu widzenia praktyki terapeutycznej należałoby uwzględnić w eksploracjach zmienne, takie jak: radzenie sobie ze stresem, empatia czy spostrzeganie wsparcia. Niejednoznaczne wyniki dokonanych analiz są także efektem zastosowania różnych technik pomiaru, doboru zróżnicowanych wiekowo grup oraz kontekstów społeczno-kulturowych badań. 


\section{Konsekwencje poczucia osamotnienia}

Związki z innymi ludźmi przynoszą każdemu psychologiczne korzyści, jednak ludzie różnią się siłą pragnienia nawiązywania relacji z innymi. Negatywny trening społeczny niektórych osób staje się źródłem dyskomfortu, który przybiera postać lęku społecznego. Sprzyja on dokonywaniu negatywnych wyborów w kwestii zachowania, które mogą zniechęcać innych do wchodzenia w kontakty, co może sprzyjać poczuciu osamotnienia. Problem pojawia się wtedy, gdy to poczucie nabiera długotrwałego charakteru [Crisp, Turner 2009, s. 302].

\section{Konsekwencje psychofizyczne poczucia osamotnienia}

Ciągłe odczuwanie osamotnienia prowadzi do niekorzystnych konsekwencji zarówno psychofizycznych, jak psychospołecznych. Badania J. Bowlby'ego i R. Spitza [Vasta i in. 1995], dotyczące znaczenia przywiązania, ujawniły, że dzieci pozbawione indywidualnej opieki i niemające okazji do stworzenia satysfakcjonującej relacji z osobą znaczącą rozwijały się gorzej pod względem poznawczym i psychofizycznym. Długotrwała frustracja potrzeby kontaktu, miłości i bezpieczeństwa prowadziła do zahamowania wzrostu, utraty wagi, licznych chorób, a także większej śmiertelności w tej grupie.

Konsekwencje poczucia osamotnienia i alienacji są obserwowalne $\mathrm{w}$ sferze "Ja" w postaci apatii, rozpaczy, poczucia bezcelowości, bezsensu własnego życia, anomii. Natomiast w sferze społecznej manifestuje się zachowaniami ryzykownymi, takimi jak: alkoholizm, narkomania, hazard, bunt, ucieczka w chorobę, samobójstwo, przestępczość, agresja, [Czerwińska-Jakimiuk 2012; Kmiecik-Baran 1995]. Permanentne poczucie osamotnienia prowadzi do dolegliwości somatycznych, obniżenia odporności organizmu, nerwic, depresji, zaburzeń osobowości (szczególnie borderline, schizoidalnej, paranoidalnej), psychoz [Jakubik, Kraszewska 2002; Mushtaq i in. 2012]. Może również skutkować zaburzeniami jedzenia, dysfunkcjami seksualnymi czy niedostosowaniem emocjonalno-społecznym [Rembowski 1992]. Konsekwencje są widoczne również w funkcjonowaniu psychospołecznym jednostki, w postaci zachwiania tradycyjnych wzorców osobowych i systemów wartości, rozbieżności między normami moralnymi a rolami społecznymi pełnionymi przez jednostkę, brakiem autorytetów, zmianami w tradycyjnym modelu rodziny i pozycji jej członków oraz konfrontowaniem się tego modelu ze współcześnie obowiązującym modelem [Gajda 1987].

Poczucie osamotnienia może przyczynić się do apatii, a nawet utraty chęci życia. Osoby poddawane oddziaływaniom resocjalizacyjnym w większości odczu- 
wają stan bycia niepotrzebnymi dla świata z powodu różnych czynników społecznych odpowiedzialnych za ich proces dezintegracyjny [Bałandynowicz 2015], który sprzyja zachowaniom suicydalnym. Wśród czynników suicydogennych pojawiają się zarówno samotność, jak i poczucie osamotnienia oraz bezsensu istnienia [Łuczak, Łuczak 2013]. Badania na temat zależności pomiędzy depresją a poczuciem osamotnienia wykazały, że prawdopodobnie obydwa zjawiska są ze sobą ściśle powiązane [Hojat 1982; Solano, Batten, Parish 1980, 1982, za: Rembowski 1989]. M. Oleś [2006] dokonała charakterystyki psychologicznej dzieci o wysokim i niskim poczuciu osamotnienia, stwierdzając, że dzieci osamotnione są bardziej zamknięte w sobie, emocjonalnie wrażliwe, bardziej submisyjne i refleksyjne w porównaniu z dziećmi towarzyskimi. Cechy te mogą predysponować je do zaburzeń nastroju i pesymistycznego nastawienia do przyszłości. Osoby odczuwające osamotnienie częściej manifestowały zaburzenia depresyjne, nasilony neurotyzm i psychotyzm, a także wrogość, niepokój, trudności komunikowania się [Mijusković 1983, 1985, za: Rembowski 1989].

Jednak K. Rook [1984] uważa, że istnieją zasadnicze różnice pomiędzy depresją a poczuciem osamotnienia, ponieważ depresja wiąże się z ogólnie obniżonym nastrojem i brakiem satysfakcji we wszystkich obszarach funkcjonowania, podczas gdy samotność zazwyczaj ogranicza się tylko do kontaktów interpersonalnych. Ponadto osoby samotne mają nadzieję, że ich problemy rozwiążą silne i satysfakcjonujące relacje, podczas gdy w depresji oczekiwania wobec przyszłości są zawsze pesymistyczne [Mushtaq i in. 2014]. W przypadku depresji odczuwanie osamotnienia stanowi jeden z podstawowych objawów osiowych, dlatego występowanie pozytywnych korelacji pomiędzy tymi zmiennymi jest zgodne z oczekiwaniami.

\section{Zaburzenia zachowania}

Symptomy poczucia osamotnienia możemy odnaleźć w klasyfikacjach zaburzeń w zachowaniu. W typologii K. Christiansena [1967, za: Urban 2007] przybiera ono postać „chronicznego przejawiania nieszczęśliwości i depresji; przejawów nieuzasadnionego lęku, bojaźliwości lub wzmożonego napięcia; preferowaniem indywidualnych (samotnych) prac i zabaw; trzymaniem się z daleka od innych, oporami przed zwróceniem się o pomoc do innych osób". Częściowo pokrywa się to $\mathrm{z}$ zahamowaniem $\mathrm{w}$ typologii $\mathrm{H}$. Stotta oraz z zachowaniami internalizacyjnymi w klasyfikacji Th. Achenbacha [Urban 2007], w której jednostki stają się ofiarami i są odrzucane przez rówieśników. Integracja z grupą rówieśniczą pojawia się również $\mathrm{w}$ zaburzeniach zachowania $\mathrm{z}$ nieprawidłowym procesem socjalizacji 
w klasyfikacji wg ICD-10, poza tym kryterium wymieniono również nieprawidłowe relacje $\mathrm{z}$ innymi, izolację od grupy połączoną z byciem osobą niepopularną oraz spędzanie czasu w samotności. Kryteria te odnoszą się również do osób dorosłych. Rozpoznanie takie zostało uznane za lepiej lokujące, gdyż socjalizacja podkulturowa może być zastąpiona socjalizacją do innej, akceptowalnej społecznie grupy.

Okazuje się, że samotność i poczucie osamotnienia mogą być czynnikami ryzyka dla zachowań impulsywnych, agresywnych i konfliktowych. Badania Dołęgi [2003] wskazują, że wśród uczniów szkół średnich poczucie samotności koreluje z agresją (głównie fizyczną) i zachowaniami antyspołecznymi. Ponadto osoby takie nie wykazują poczucia winy, co jest charakterystyczne dla osobowości antyspołecznej. Nadmierna koncentracja na sobie i negatywnych emocjach towarzyszących samotności powoduje brak wrażliwości na potrzeby innych osób, a gromadzące się emocje znajdują ujście właśnie w postaci agresji [Tomaszek, Tucholska 2012].

\section{Odrzucenie rówieśnicze}

Poczucie osamotnienia jest wzmagane przez takie sytuacje, jak odrzucanie i izolowanie dziecka w grupie, brak grupy odniesienia i ogólnie niski status socjometryczny, chociaż J. Rembowski [1992] w swoich badaniach nie potwierdził znaczenia statusu socjometrycznego dla odczuwania samotności. Próby porównania dzieci i młodzieży z wysokim i niskim statusem socjometrycznym przyniosły dość zróżnicowane wyniki w zależności od etapu edukacyjnego [Parhurts, Asher 1992] i płci [Storch i in. 2003]. Najczęściej dzieci odrzucane przez rówieśników prezentowały typ zaburzeń internalizacyjnych charakteryzujących się lękiem i wycofaniem, unikaniem kontaktów społecznych, jednak wśród nich były również dzieci agresywne. K. Musialska [2011] w grupie dzieci odrzuconych wyodrębnia następujące typy dzieci odrzuconych: odrzucone - agresywne, odrzucone - wycofane, odrzucone - nieagresywne, odrzucone - uległe oraz odrzucone socjometrycznie wybitnie, silnie i słabo. Odrzucenie rówieśnicze prowadzi do nasilania się lęku społecznego, mniej efektywnego radzenia sobie ze stresem i poczucia osamotnienia. Próby przeanalizowania znaczenia tego typu doświadczeń $\mathrm{w}$ modelu podłużnym wskazują, że odrzucenie rówieśnicze w wieku wczesnoszkolnym prowadzi do nasilania symptomów depresji, zaburzeń internalizacyjnych i obniżenia poziomu kompetencji społecznych. Dodatkowo stanowi ono silny stresor, z którym jednostka będzie próbowała sobie poradzić [Szwejka 2011]. 
Niebezpieczną konsekwencję odrzucenia stanowi dręczenie rówieśnicze (bullying) [Tłuściał-Deliowska 2017; Jaworska 2012], które obecnie stało się jeszcze łatwiejsze do wdrożenia za sprawą nowoczesnych technologii komunikacyjnych (cyberbullying) [Pyżalski 2012].

\section{Wiktymizacja}

W literaturze przedmiotu nie kwestionuje się znaczenia środowiskowych czynników kryminogennych, m.in. w socjalizacji sprawców zabójstw, choć nie przesądza to o popełnieniu przestępstwa przez jednostkę, która wcześniej występowała w roli ofiary [por. Kowalczyk 2010].

Proces „stawania się ofiarą" jest w literaturze określany mianem wiktymizacji. Stanowi on wynik doświadczenia przez jednostkę wydarzenia o silnym negatywnym ładunku emocjonalnym - traumatyzującego, które w przyszłości skutkuje byciem przez nią ofiarą przemocy. Wydarzenie to wiąże się ze szkodą jednostkimaterialną, moralną lub psychiczną. Jak wynika z badań wiktymizacja nie musi stanowić incydentalnego wydarzenia. Wiktymizacja wtórna charakteryzuje się ponownym doznaniem przez ofiarę krzywdy, np. w związku z postępowaniem procesowym [Paluch 2013]. Zgodnie z teorią sprawiedliwego świata M. Lernera przyczyny "pokrzywdzenia” lokowane są w osobie ofiary. Podobnie działa tzw. efekt pewności wstecznej (hindsight bias), gdy znając konsekwencje jakiegoś wydarzenia poszukuje się przyczyn, które mogły poprzedzić jego zajście. Zaburzeniem współwystępującym może być zespół stresu pourazowego [Kołakowski 2013], a w konsekwencji wiktymizacja.

Jednostka słabsza od sprawcy jest bardziej podatna na stanie się ofiarą dręczenia rówieśniczego (bullying) [Tłuściał-Deliowska 2017]. Potencjał wiktymogenny dostrzeżono także u osób ze specjalnymi potrzebami edukacyjnymi [Plichta, Olempska-Wysocka 2013, 2014].

Otwarta i relacyjna wiktymizacja pozytywnie koreluje z dystresem, lękiem przed negatywną oceną, społecznym wycofaniem i samotnością [Storch, Brassard, Masia-Warner 2003], jak wynikało z badań w grupie 238 adolescentów w wieku 13-16 lat. Ważniejsza okazała się być wiktymizacja relacyjna, która nie koresponduje z płcią osób badanych. U chłopców ujawniono wyższy poziom otwartej wiktymizacji niż u dziewczynek. Ponadto wykazano, że pomiędzy przyjaźnią a samotnością istnieje zależność o charakterze krzywoliniowym. 


\section{Uzależnienia}

Badania poczucia osamotnienia w grupie osób uzależnionych koncentrowały się głównie na alkoholikach. Podobnie jak w przypadku cech osobowości mechanizm zależności pomiędzy nałogiem a poczuciem osamotnienia ma charakter sprzężenia zwrotnego. Osoby uzależnione traktują najczęściej alkohol jako środek ułatwiający im radzenie sobie ze stresem, który łagodzi przykre stany samotności. Jednocześnie w miarę pogłębiania się nałogu następuje odizolowanie się tych osób od dotychczasowego środowiska. Kobiety najczęściej piją w ukryciu, natomiast mężczyźni w towarzystwie innych uzależnionych.

A. Jakubik, E. Kraszewska [2002] zbadali grupę 60 mężczyzn uzależnionych od alkoholu i 60 nieuzależnionych w wieku 30-45 lat. Okres nadużywania wynosił 10-15 lat. Analizy dotyczyły poczucia alienacji we wszystkich jej wymiarach. Okazało się, że grupa uzależnionych różniła się od grupy kontrolnej w zakresie poczucia bezsensu, bezsilności, samowyobcowania, osamotnienia. Konsekwencją takiej konfiguracji cech było przekonanie o braku jasnych i spójnych zasad, przekonanie o braku wpływu na własne życia i atrybucja zewnętrzna przyczyn zdarzeń. Jednocześnie alkoholicy deklarowali silną potrzebę wsparcia społecznego. J. Chodkiewicz, M. Świątkowska [2007] na podstawie badań grupy 72 alkoholików w wieku 22-64 wykazali, że wsparcie społeczne, integracja społeczna, zadowolenie z własnej osoby i stanu zdrowia wyjaśniają 85\% zmienności wyników $\mathrm{w}$ zakresie osamotnienia. Zmienne te decydują o utrzymaniu abstynencji. Kobiety alkoholiczki manifestują wyższy poziom poczucia osamotnienia, natomiast alkoholicy dłużej nadużywający niższy poziom osamotnienia [Medora, Woodward 2001]. Być może w tym drugim przypadku identyfikacja z podkulturą alkoholową łagodzi poczucie oderwania od ważnych osób, albo jest to wynikiem degradacji osobowości szczególnie w sferze uczuciowości.

Leczenie alkoholizmu wymaga zmiany środowiska, co pogłębia osamotnienie osób chorych, dlatego należy zaangażować je w pracę grupy samopomocowej, włączyć rodzinę w proces terapii, udzielić wsparcia ze strony terapeuty, pomocy medycznej w przezwyciężaniu dolegliwości somatycznych.

Podobnych związków dopatruje się w kwestiach uzależnienia od Internetu i innych technologii cyfrowych, jednak tutaj bardziej adekwatny zdaje się być termin patologicznego używania, który nie wyklucza możliwości nauczenia jednostki zdrowego korzystania z nich [Jędrzejko, Morańska 2011, 2013].

Implikacje praktyczne

Liczne i zróżnicowane kontakty społeczne determinują prawidłowy rozwój społeczny człowieka. Jest to szczególnie istotne w przypadku osób nieprzystosowanych społecznie. K. Porębska [2010] podkreśla, że bez kontaktów ze społeczeń- 
stwem skazany nie jest w stanie rozwinąć się w sferze psycho-socjo-społecznej. W koncepcji społecznej deizolacji więzień A. Bałandynowicza [2015], zaangażowanie osób spoza zakładów karnych jest szansą na zwiększenie skuteczności oddziaływań penitencjarnych poprzez podniesienie jakości kontaktów społecznych. W kwestii jakości nawiązywanych relacji istotne znaczenie ma samoocena. Człowiek z obniżoną samooceną jest podatny na komplementy i wyrazy zainteresowania swoją osobą, dlatego jest w stanie zaakceptować niemal każdego. Ponadto większość ludzi obawia się odrzucenia, przez co są skłonni do podejmowania w sposób impulsywny nierozsądnych decyzji [Aronson, Aronson 2011]. Tym samym ważne jest objęcie szczególną opieką osób trafiających, ale również opuszczających placówki izolacyjne, też opiekuńczo-wychowawcze, aby umożliwić im nawiązywanie wartościowych kontaktów społecznych. Ponadto zmniejszyć możliwość wchodzenia przez nich do grup i środowisk zdemoralizowanych, gdzie zyskanie aprobaty będzie uzależnione od podejmowania działalności pozostającej w sprzeczności z normami społecznymi i przepisami prawa [Pospiszyl 2012] i odpowiednio wcześnie zahamować cykl „kariery instytucjonalnej” [Szczepanik 2015]. Kluczowe wydaje się być wzmacnianie zasobów osobistych osób nieprzystosowanych społecznie już na etapie instytucji przez pracę nad podniesieniem ich poziomu samooceny, bardziej adekwatnym spojrzeniem na siebie i otaczający świat, rozwijaniem umiejętności społecznych. Podobnie w przypadku osób ze specjalnymi potrzebami edukacyjnymi [Plichta, Olempska-Wysocka 2013, 2014]. Przydatne do tego może być uczestnictwo w różnego rodzaju treningach umiejętności społecznych [Glick, Gibbs 2011] czy zajęciach socjoterapeutycznych [Sawicka 2010]. Decyzja o zmianie swojego życia czy znalezieniu w sobie motywacji do zmiany należy do jednostki, jednak specjaliści mogą przygotować atrakcyjną ofertę oddziaływań, motywować do uczestnictwa w nich i pomagać odnaleźć się w pozytywnie funkcjonującej grupie odniesienia. Działania te można podejmować już na etapie instytucji socjalizacyjnych [Hołyst 2013].

\section{Podsumowanie i wnioski}

Dokonany przegląd zagadnień dotyczących poczucia osamotnienia oraz korespondujących $\mathrm{z}$ nim zjawisk samotności $\mathrm{i}$ alienacji wskazuje na ich silne powiązania z problematyką nieprzystosowania społecznego. Zmiany społeczne i obyczajowe oraz postęp technologiczny są powodem nasilania się poczucia osamotnienia współczesnego człowieka. Prowadzi to do zmian w sferze "Ja" i sferze społecznej manifestujących się symptomami w postaci: zachowań ryzykownych, agresji, przestępczości, prób samobójczych uzależnień i wiktymizacji. 
Należałoby zatem uznać, że poczucie osamotnienia jest jednym z ważnych czynników ryzyka nieprzystosowania społecznego i powinno być uwzględniane zarówno w procesie diagnozy, jak i resocjalizacji. Trudno jest jednak jednoznacznie określić kierunek zależności pomiędzy tymi zmiennymi, ponieważ poczucie osamotnienia może być zarówno przyczyną, jak i skutkiem nieprzystosowania społecznego. Proponowane kierunki działań naprawczych wskazują, że metodami zapobiegania i terapii poczucia osamotnienia mogą być szeroko rozumiane interwencje polegające na rozwijaniu umiejętności społecznych, np. przez treningi i stwarzanie okazji do interakcji społecznych, udzielanie społecznego wsparcia i wczesne rozpoznawanie symptomów niedostosowania społecznego. Dodatkowo zalecane są działania informacyjne, programy interwencyjne ukierunkowane na pracę z całą społecznością, działania kontrolne czy wdrażanie nauki przebaczania [Jaworska 2012]. Towarzyszyć temu miałoby zerwanie z nadmiarem punitywności wszechobecnym zarówno $w$ oddziaływaniach wychowawczych, jak i resocjalizacyjnych [Bartkowicz 2011].

Kierunki przyszłych badań powinny skoncentrować się na problematyce skuteczności resocjalizacji w pokonywaniu poczucia osamotnienia szczególnie tych osób, które przebywają w zakładach karnych lub placówkach opiekuńczo-wychowawczych. Jak pokazują najnowsze badania, problemy rozpoczynają się już na etapie szkoły [Tłuściał-Deliowska 2017]. Ważna jest także profilaktyka pierwszorzędowa ukierunkowana na dzieci i młodzież, która powinna dotyczyć relacji rodzinnych, szkolnych i rówieśniczych ze szczególnym uwzględnieniem zagrożeń cywilizacyjnych.

\section{Bibliografia}

Argyle M. (1999), Psychologia stosunków międzyludzkich, PWN, Warszawa.

Aronson E., Aronson J. (2011), Człowiek istota społeczna, Wydawnictwo Naukowe PWN, Warszawa.

Bałandynowicz A. (2015), Probacyjna sprawiedliwość karzaca, Wolters Kluwer SA, Warszawa.

Bartkowicz Z. (2011), Agresywność osób wykolejonych jako wyzwanie dla resocjalizacji [w:] Tożsamość osobowa dewiantów a ich reintegracja spoteczna, A. Kieszkowska (red.), Oficyna Wydawnicza „Impuls", Kraków, s. 425-430.

Chodkiewicz J., Świątkowska M. (2007), Poczucie osamotnienia a wsparcie społeczne i zadowolenie z życia u mężczyzn uzależnionych od alkoholu, „Acta Lodiensis Folia Psychologia”, $\mathrm{nr}$ 11, s. 81-95.

Crisp R.J, Turner R.N. (2009), Psychologia spoteczna, Wydawnictwo Naukowe PWN, Warszawa.

Czerwińska-Jakimiuk E. (2012), Poczucie alienacji u młodzieży a jego osobowościowe i społeczne korelaty, ,Normy, Dewiacje i Kontrola Społeczna”, nr 13, s. 357-373.

Dołęga Z. (2003), Samotność młodzieży-analiza teoretyczna i studia empiryczne, Wydawnictwo UŚ, Katowice.

Gajda J. (1987), Samotność i kultura, Warszawa. 
Glick B., Gibbs J.C. (2011), Trening Zastępowania Agresji (ART) Kompleksowa interwencja wobec młodzieży agresywnej, Instytut "Amity”, Warszawa.

Heiman T., Margalit M. (1998), Loneliness, Depression, and Social Skills among Students with Mild Mental Retardation in Diffrent Educational Settings, "Journal of Special Education", vol. 32, no. 3, s. 154-163.

Hołyst B. (2013), Zagrożenia ładu społecznego, Wydawnictwo Naukowe PWN, Warszawa.

Jakubik A., Kraszewska E. (2002), Zespót alienacyjny u mężczyzn uzależnionych od alkoholu, „Alkoholizm i Narkomania", vol. 15(1), s. 95-106.

Jaworska A. (2012), Leksykon resocjalizacji, Oficyna Wydawnicza „Impuls”, Kraków.

Jędrzejko M., Morańska D. (2011), Uzależnienie czy cyber - zaburzenie? [w:] M. Walancik, J. Hroncowá, Pedagogika społeczna wobec procesów żywiołowych i zachowań ryzykownych, s. 107-131.

Jędrzejko M., Morańska D. (2013), Pułapki wspótczesności, część I: Cyfrowi Tubylcy - socjopedagogiczne aspekty nowych technologii cyfrowych, Wyższa Szkoła Biznesu w Dąbrowie Górniczej, Dąbrowa Górnicza-Warszawa.

Kleszcz M., Łączyk M. (2012), Młodzież licealna wobec wartości, samotności i pasji, Oficyna Wydawnicza „Impuls”, Kraków.

Kmiecik-Baran (1995), Poczucie alienacji: destruktywne i konstruktywne sposoby minimalizacji, Gdańsk.

Kołakowski A. (2013), Diagnoza zaburzeń zachowania [w:] Zaburzenia zachowania u dzieci. Teoria i praktyka, A. Kołakowski (red.), Gdańskie Wydawnictwo Psychologiczne, Sopot, s. 152-192.

Kościelak R. (1996), Funkcjonowanie psychospołeczne a upośledzenie umysłowe, WSiP, Warszawa.

Kowalczyk M.H. (2010), Zabójcy i mordercy. Czynniki ryzyka i możliwości oddziatywań resocjalizacyjnych, Oficyna Wydawnicza „Impuls”, Kraków.

Łuczak E., Łuczak W. (2013), Dynamika zachowań suicydalnych i ich niektóre korelaty [w:] Pedagogika społeczna wobec procesów żywiołowych i zachowań ryzykownych, M. Walancik, J. Hroncová (red.), Wydawnictwo Edukacyjne Akapit, Toruń, s. 75-83.

Medora N.P., Woodward J.C. (2001), Factors Associated with Loneliness Among Alcoholics in Rehabilitation Centers, "The Journal of Social Psychology", vol. 13(6), s. 769-779.

Mushtaq R., Shoib S., Shah T., Mushtaq S., (2014), Relation between Loneliness, Psychiatric Disorders and Physical Health? A Review on the Psychological Aspects of Loneliness, "Journal of Clinical and Diagnostic Research", vol. 8(9), s. 1-3.

Musialska K. (2011), Odrzucenie w klasie szkolnej, Oficyna Wydawnicza „Impuls”, Kraków.

Niewiadomska I., Chwaszcz J. (2010), Jak skutecznie zapobiegać karierze przestępczej?, Lublin, s. 85-102.

Oleś M. (2006), Psychologiczna charakterystyka dzieci o wysokim i niskim poczuciu osamotnienia, „Roczniki Psychologiczne”, t. IX, nr 1, s. 121-140.

Paluch A. (2013), Wtórna wiktymizacja czyli ponowne krzywdzenie, https://psychologikaprawnika.pl/2013/02/26/wtorna-wiktymizacja-czyli-ponowne-krzywdzenie/ [dostęp: 5.05.2017].

Papoutsaki K., Gena A., Kalyva E. (2013), How Do Children with Mild Intellectual Disabilitiea Perceive Loneliness?, „Europe's Journal of Psychology”, nr 9(1), s. 51-61. 
Parkhurst J.T., Asher S.R. (1992), Peer rejection in Middle School: Subgroup Differences in Beahavior, Loneliness, and Intepersonal Concerns, "Developmental Psychology”, vol. 29(20), s. 231-242.

Perski A.(2002), Poradnik na czas przełomu, Wydawnictwo Santorski \& Co, Warszawa.

Plichta P., Olempska-Wysocka M. (2013), Narażenie na agresję rówieśniczą niepetnosprawnych uczniów szkót integracyjnych w relacjach nauczycieli wspomagajacych, "Studia Edukacyjne”, nr 28, www.repozytorium.amu.edu.pl.

Plichta P., Olempska-Wysocka M. (2014), Agresja rówieśnicza wobec uczniów ze specjalnymi potrzebami edukacyjnymi w relacjach pracowników poradni psychologiczno-pedagogicznych, www.researchgate.net.

Porębska K. (2010), Pozytywne i negatywne czynniki determinujace proces readaptacji spotecznej osób opuszczających zakłady karne [w:] Zachowania przestępcze. Przyczyny i zapobieganie, F. Kozaczuk (red.),Wydawnictwo Uniwersytetu Rzeszowskiego, Rzeszów, s. 470-479.

Pospiszyl I. (2012), Identyfikacja z grupa jako sposób rozwiązywania problemów własnej tożsamości [w:] Tożsamość grupowa dewiantów a ich reintegracja społeczna, część II, W. Ambrozik, A. Kieszkowska (red.), Oficyna Wydawnicza „Impuls”, Kraków, s. 53-61.

Pyżalski J. (2012), Agresja elektroniczna i cyberbullying jako nowe ryzykowne zachowania młodzie$\dot{z} y$, Oficyna Wydawnicza „Impuls”, Kraków.

Rembowski J. (1989), Poczucie osamotnienia w świetle teorii i niektórych technik pomiarowych, „Kwartalnik Pedagogiczny", nr 4, s. 3-11.

Rembowski J. (1992), Samotność, UG Gdańsk.

Rook K.S. (1984), Research on Social Support, Loneliness and Social Isolation, „Review of Personality and Social Psychology", no. 5, s. 240-264.

Sawicka K. (red.) (2010), Socjoterapia, Wydawnictwo KOMPENDIUM, Warszawa.

Sendyk M. (1989), Osamotnienie jako konsekwencja zaburzeń więzi emocjonalnych w rodzinie, „Wychowanie w Rodzinie”, t. 4, s. 139-150.

Sharabi A., Levi U., Margalit M. (2012), Children's Loneliness, Sense of Coherence, Family Climate, and hope:Developmental Risk and Protective Factors, „The Journal of Psychology”, vol. 146(1-2), s. 61-83.

Shaughnessy K. (2008), Loneliness in Childre, „Journal of Jewish Communal Service”, vol. 83, no. 2/3, s. 194-200.

Storch E.A., Brassard M.R., Masia-Warner C.L. (2003), The Relation of Peer Victimization to Social Anxiety and Loneliness in Adolescence, "Child Study Journal”, vol. 33, no. 1, s. 1-18.

Szczepanik R. (2015), Stawanie się recydywistą. Kariery instytucjonalne osób powracających do przestępczości, Wydawnictwo Uniwersytetu Łódzkiego, Łódź.

Szczupał B. (2005), Poczucie samotności dziecka przewlekle chorego jako problem pedagogiczny [w:] Edukacja-socjalizacja-autonomia w życiu osoby niepetnosprawnej, A. Klinik, J. Rottermund, Z. Gajdzica (red.), Oficyna Wydawnicza „Impuls”, Kraków, s. 109-118.

Szwejka Ł. (2011), Odrzucenie rówieśnicze - przesłanki dla praktyki pedagogicznej na terenie szkoły [w:] W. Ambrozik, A. Kieszkowska, Tożsamość grupowa dewiantów a ich reintegracja społeczna, Oficyna Wydawnicza „Impuls”, Kraków, s. 143-151.

Tłuściał-Deliowska A. (2017), Dręczenie rówieśników jako strategia osiagania własnych celów w świetle badań nad społeczną dominacją i działaniami przymuszającymi, „Rozprawy Społeczne" $^{\prime \prime}$ t. 11, nr 2, www.researchgate.net. 
Tłuściał-Deliowska A. (2017), Dręczenie szkolne. Społeczno - pedagogiczna analiza zjawiska, Wydawnictwo APS, Warszawa.

Tomaszek K., Tucholska S. (2012), Psychospołeczne następstwa poczucia alienacji u młodzieży, „Pedagogika Christiana”, nr 2/30, s. 163-178.

Tracz M. (2010), Samotność a poczucie koherencji wychowanków domu dziecka, Lubelski Rocznik Pedagogiczny, t. XXIX, s. 75-87.

Urban B. (2007), Zaburzenia w zachowaniu i niedostosowanie społeczne w świetle wspótczesnych wyników badań [w:] B. Urban, J.M. Stanik, Resocjalizacja, t. 1, Pedagogium Wyższa Szkoła Pedagogiki Resocjalizacyjnej, Wydawnictwo Naukowe PWN, Warszawa, s. 136-167.

Vasta R., Haith M.M., Miller (1995), Psychologia dziecka, WSiP Warszawa. 